\title{
Analisa Heat Input Pengelasan terhadap Distorsi, Struktur Mikro dan Kekuatan Mekanis Baja A36
}

\author{
Heri Wibowo 1 , M.Noer IIman², PriyoTri Iswanto 3 \\ 1,2,3 Teknik Mesin dan Industri, Universitas Gadjah Mada, Jl. Grafika no 2 Yogyakarta 55281 \\ E-mail address: heriwbuny@yahoo.com
}

\begin{abstract}
The minimization of weld distortion has become an important subject of research in welding. Severe distortion can cause undesirable influence on the cost of fabrication since additional work or repair needs to be performed. In addition, distortion also reduce dimensional accuracy and even loss of structural integrity. The present investigation aims to reduce welding distortion on A36 steel by controlling heat input during Metal Inert Gas (MIG) welding. The welding process was carried out by maintaining constant voltage and current of 23 Volt and 145 Ampere respectively whereas travel speed was varied in the range of 3.9 to $4.9 \mathrm{~mm} / \mathrm{s}$ giving heat input of 678 to $936 \mathrm{~J} / \mathrm{mm}$. Result of this investigation showed that the welding distortion was achieved at the heat input of $756 \mathrm{~J} / \mathrm{mm}$. At this heat input, the percentage of acicular ferrite is maximized resulting in good weld impact toughness.

Keywords: heat input, distortion, microstructure
\end{abstract}

\section{PENDAHULUAN}

Teknik Pengelasan digunakan secara intensif pada berbagai industri manufaktur, seperti: otomotif, perkapalan, pesawat terbang, kereta api, konstruksi jembatan, bejana tekan, dan sebagainya. Teknik pengelasan memiliki berbagai keuntungan untuk produksi seperti hemat biaya, akurasi ukuran, dan variasi bentuk struktur las. Disamping keuntungan tersebut, teknik pengelasan menimbulkan efek yang merugikan, diantaranya: perubahan struktur mikro, kekuatan dan ketangguhan bahan menurun, distorsi dan tegangan sisa. Faktor yang mempengaruhi kualitas las dimulai dari perencanaan las, persiapan pengelasan, dan prosedur saat pengelasan. Perencanaan las salah satunya adalah pengaturan heat input dapat dilakukan dengan mengatur arus, voltase atau mengatur kecepatan pengelasan. Heat input yang tinggi akan menyebabkan terjadinya distorsi yang besar baik distorsi sudut, distorsi lengkung, maupun buckling pada plat tipis [1]. Hal ini dikarenakan heat input yang besar akan menyebabkan regangan thermal yang tidak merata semakin besar sehingga regangan ini berakibat pada distorsi pada benda yang tidak ditahan pada ujungnya [2].

Heat input pada las sangat mempengaruhi struktur fase, ketangguhan, laju pendinginan serta distorsi. Komposisi kimia pada weld zone (WZ) dan level heat input secara langsung berakibat pada struktur mikro dan ketangguhan las [3]. Heat input akan mempengaruhi laju pendinginan las, yang berakibat pada perubahan struktur mikro pada las [4]. Parameter las heat input dan variabel gas pelindung akan menentukan struktur mikro, morfologi dendrite dan tekstur las yang berakibat pada ketangguhan cryogenic sambungan las [5]. Berdasarkan simulasi FEM, pengaturan heat input mampu meminimalkan distorsi las pada plat tipis dengan mengatur pada parameter las, mengubah besaran arus busur, voltase busur dan kecepatan las [6]. Distorsi sangat merugikan karena bentuk tidak sesuai dengan desain, ukuran tidak akurat, serta biaya perbaikan yang besar.
Seperti dicontohkan pada pembuatan kapal di Australia dan Selandia Baru dengan material high strength steel, distorsi akibat pengelasan tersebut akan menjadi permasalahan yang signifikan. Menurut The Welding Institute (TWI), biaya untuk memberbaiki distorsi pengelasan terhadap biaya total fabrikasi sebesar 30 \% [7]. Permasalahan distorsi pengelasan juga terjadi di industri kereta api dan perkapalan Indonesia. Gerbong kereta api mengalami distorsi antara dinding plat tipis dan frame pada pintu gerbong, sedangkan industri perkapalan mengalami distorsi pada sambungan penguat (stiffeners) dengan plat tipis dinding kapal. Penelitian sebelumnya banyak memfokuskan penerapan heat input dan metode las untuk memperbaiki ketangguhan pada las, struktur mikro dan distorsi, namun belum membahas keseluruhan mengenai korelasi distorsi, siklus thermal, struktur mikro dan kekuatan mekanis las. Pada penelitian ini akan dibahas pengaruh heat input pada baja A 36 tebal $4 \mathrm{~mm}$ untuk mengoptimalkan distorsi dan sifat mekanis sambungan las, serta hubungan heat input dengan mikrostruktur las.

\section{METODE PENELITIAN Bahan}

Plat baja A36 dengan ketebalan $4 \mathrm{~mm}$ digunakan sebagai logam induk (base metal).

Tabel 1. Komposisi kimia bahan baja karbon rendah A36 [8] dan elektroda ER70S-6 [9].

\begin{tabular}{lcccccc}
\hline & \multicolumn{7}{c}{ Komposisi } \\
Bahan & $\mathrm{C}$ & $\mathrm{P}$ & $\mathrm{S}$ & $\mathrm{Si}$ & $\mathrm{Cu}$ & $\mathrm{Mn}$ \\
& $(\%)$ & $(\%)$ & $(\%)$ & $(\%)$ & $(\%)$ & $(\%)$ \\
\hline Baja & $\max$ & $\max$ & $\max$ & $\max$ & $\max$ & - \\
karbon & 0,25 & 0,04 & 0,05 & 0,4 & 0,2 & \\
rendah & & & & & & \\
$\begin{array}{l}\text { A36 } \\
\text { Elektroda } \\
\text { ER70S-6 }\end{array}$ & 0,10 & 0,11 & 0,12 & 0,88 & 0,24 & 1,56 \\
\hline
\end{tabular}


Sedangkan elektroda jenis ER70S-6 diameter 0,8 mm digunakan sebagai filler dalam proses pengelasan. Komposisi kimia baja A36 dan elektroda ER70S-6 ditampilkan pada Tabel 1.

\section{Sumber Panas Las}

Masukan panas atau heat input $(\mathrm{HI})$ yang digunakan untuk melakukan sambungan las berasal dari busur listrik dengan menggunakan Persamaan 1.

$$
\mathrm{HI}=\eta x \frac{\text { Tegangan las }(V) x \operatorname{Arus~las}(I)}{\text { Kecepatan Las }(v)}
$$

dengan : $\eta=$ efisiensi panas las

Besaran tegangan busur las (V) dan arus busur las (I) merupakan parameter yang dapat diatur dari mesin las. Sedangkan kecepatan las (v) dapat diatur dari peralatan welding rig.

\section{Proses pengelasan}

Sambungan las dilakukan pada plat baja A36 dengan dimensi $400 \mathrm{~mm} \times 100 \mathrm{~mm} \times 4 \mathrm{~mm}$. Plat baja disiapkan dengan bentuk sambungan tumpul tipe $\mathrm{V}$, dengan memberikan kemiringan 30 derajad pada kedua ujung yang akan dilas dengan root pass $1-2$ $\mathrm{mm}$. Termokopel dipasangkan pada 4 titik benda uji masing-masing pada jarak $4 \mathrm{~mm}, 10 \mathrm{~mm}, 30 \mathrm{~mm}$ dan $70 \mathrm{~mm}$ untuk mendeteksi suhu pada titik yang diukur. Benda kerja dilas dengan las GMAW yang dioperasikan secara otomatis dengan bantuan peralatan welding rig dengan ukuran benda kerja dan titik termokopel sesuai Gambar 1. Parameter untuk pengelasan GMAW dengan bahan baja karbon tebal $4 \mathrm{~mm}$ menggunakan elektroda ER70S-6 diameter elektroda 0,8 mm, Wire feed $135 \mathrm{~mm} /$ detik, dan debit gas 5 liter/menit ditampilkan pada Tabel 2 [10].

Tabel 2. Parameter pengelasan GMAW

\begin{tabular}{ccccc}
\hline Sampel & \multicolumn{3}{c}{ Parameter las } & Heat \\
& $\begin{array}{c}\text { Arus } \\
\text { Voltase } \\
(\mathrm{A})\end{array}$ & $\begin{array}{c}\text { Kecepatan } \\
\text { Input }\end{array}$ & $\begin{array}{c}\text { las }(\mathrm{mm} / \mathrm{dt}) \\
(\mathrm{J} / \mathrm{mm})\end{array}$ \\
\hline Las 1 & & & 3,56 & 936 \\
Las 2 & \multirow{2}{*}{145} & 23 Volt & 3,94 & 846 \\
Las 3 & & & 4,41 & 756 \\
\hline
\end{tabular}

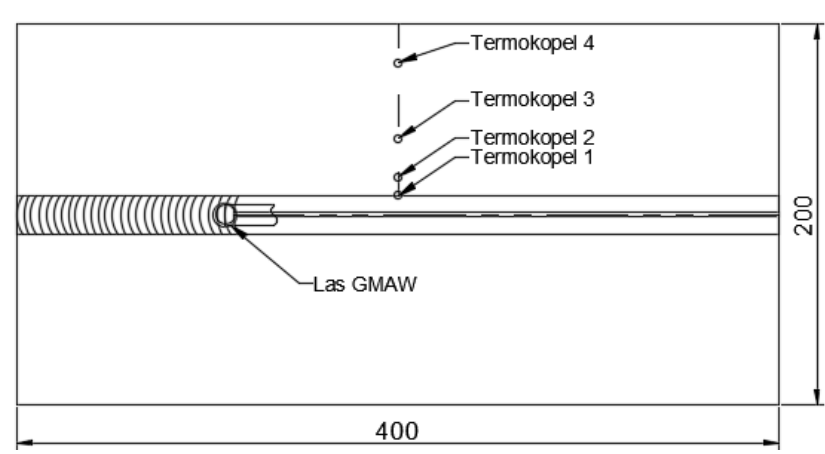

Gambar 1. Ukuran benda kerja las dan titik termokopel
Penelitian ini memakai 3 variasi heat input yaitu $936 \mathrm{~J} / \mathrm{mm} ; 846 \mathrm{~J} / \mathrm{mm}$ dan $756 \mathrm{~J} / \mathrm{mm}$. Heat input dihitung dengan persamaan 1 dengan tegangan las 23 volt, arus las 145 ampere, efisiensi panas (n) diasumsikan $100 \%$ dan kecepatan pengelasan (v) divariasi masing-masing 3,$56 ; 3,94$ dan 4,41 $\mathrm{mm} /$ detik.

\section{Uji distorsi}

Pengukuran distorsi dilakukan dengan metode fixed point menggunakan alat dial indicator, dengan tingkat akurasi ketelitian sebesar 0,01 mm. Posisi pengukuran dial indicator ditunjukkan pada Gambar 2.

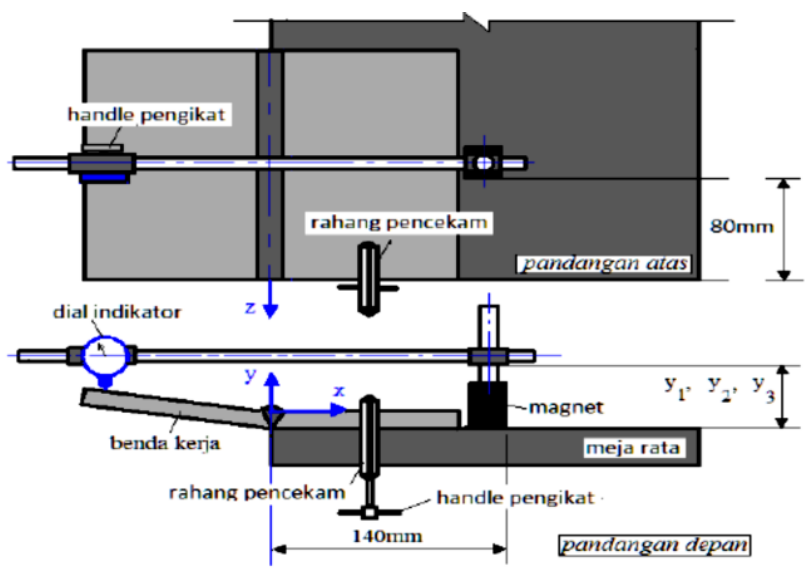

Gambar 2. Pengukuran distorsi dengan dial indicator [11].

\section{Pengamatan Struktur Mikro}

Pengamatan struktur mikro pada sambungan las dilakukan dengan mikroskop optik dengan perbesaran 100 x lensa obyektif. Spesimen disiapkan melalui 3 langkah prosedur yaitu pengamplasan, pemolesan dan etsa. Pengamatan dilakukan pada penampang melintang las khususnya di 4 daerah las yaitu weld zone (WZ), HAZ coarse grain (CG-HAZ), HAZ fine grain (FG-HAZ) and based metal (BM).

\section{Pengujian Tarik, Kekerasan dan Ketangguhan}

Pengujian kekuatan mekanis sambungan las dilakukan dengan uji tarik, uji kekerasan dan uji ketangguhan.
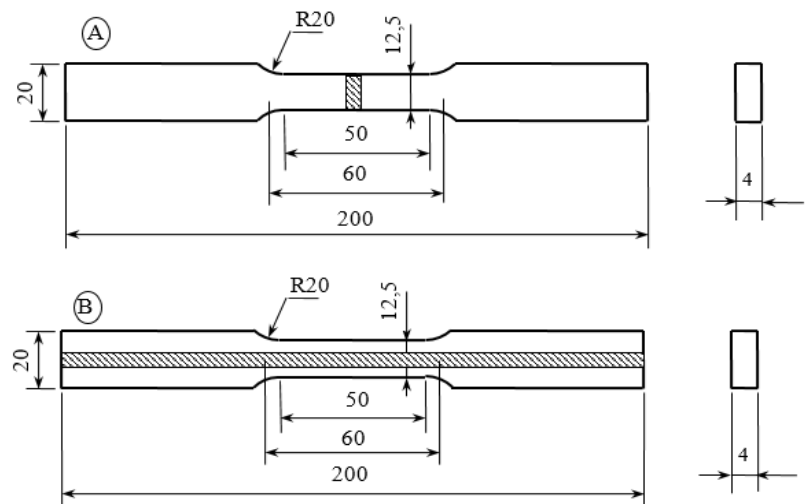

Gambar 3. Spesimen uji tarik dengan standar ASTM E-8 arah las longitudinal. 
Uji kekerasan dilakukan dengan uji Vickers dengan beban 500 grf untuk mendapatkan distribusi kekerasan pada daerah WZ, CG-HAZ, FG-HAZ and BM. Selanjutnya, uji tarik dilakukan dengan mesin Servo Pulser mengikuti standar ASTM E-8 [12]. Uji tarik dilakukan pada spesimen uji arah las transversal dan arah las longitudinal dengan ukuran spesimen sesuai Gambar 3. Pengujian ketangguhan menggunakan uji impact Charpy dengan takik V ( $V$ notch Charpy impact test). Benda uji impact sesuai dengan standar pengujian ASTM A-370 [13] ukuran spesimen subsize $4 \mathrm{~mm}$.

\section{HASIL DAN PEMBAHASAN Analisa Distorsi}

Distorsi hasil pengelasan diukur dengan alat dial indicator pada tiap titik di grid line benda kerja. Pengukuran distorsi dilakukan diseluruh permukaan setelah suhu plat mencapai suhu kamar. Distorsi yang diselidiki pada 3 plat hasil pengelasan dengan variasi heat input $(756 \mathrm{~J} / \mathrm{mm} ; 846 \mathrm{~J} / \mathrm{mm}$ and $936 \mathrm{~J} / \mathrm{mm}$ ) seperti ditunjukkan pada Gambar 4. Berdasarkan Gambar 4 ditunjukkan bahwa perbedaan heat input menyebabkan terjadinya perubahan distorsi. Hasil pengukuran menunjukkan nilai distorsi arah longitudinal pada heat input $756 \mathrm{~J} / \mathrm{mm}, 846 \mathrm{~J} / \mathrm{mm}$ and $936 \mathrm{~J} / \mathrm{mm}$ berturut-turut adalah $11,3 \mathrm{~mm}, 13,2 \mathrm{~mm}$ dan $14,1 \mathrm{~mm}$, sehingga distorsi arah longitudinal minimal terjadi pada heat input $756 \mathrm{~J} / \mathrm{m}$.

Demikian juga nilai distorsi arah transversal pada heat input $756 \mathrm{~J} / \mathrm{mm}, 846 \mathrm{~J} / \mathrm{mm}$ dan $936 \mathrm{~J} / \mathrm{mm}$, berturut-turut adalah $3,6 \mathrm{~mm}, 3,9 \mathrm{~mm}$ dan $4,0 \mathrm{~mm}$, sehingga distorsi arah transversal minimal terjadi pada heat input $756 \mathrm{~J} / \mathrm{mm}$. Dari keterangan diatas dapat menjadi acuan bahwa penurunan heat input akan memperkecil terjadinya distorsi arah longitudinal (distorsi lengkung) maupun arah transversal (distorsi sudut). Hal ini dikarenakan heat input yang rendah akan mengurangi jumlah deposit logam las (diperlihatkan di struktur makro las Gambar 6 (f), 7 (f) dan 8 (f)) sehingga penyusutan di bagian atas kampuh $\mathrm{V}$ baik arah longitudinal maupun arah transversal juga lebih kecil.

Distorsi pengelasan tersebut juga berkaitan dengan distribusi temperatur yang terjadi pada daerah las. Gambar 5 (a) dan 5 (b) memperlihatkan distribusi temperatur pada heat input $846 \mathrm{~J} / \mathrm{mm}$ dan $936 \mathrm{~J} / \mathrm{mm}$, diukur pada arah transversal dengan jarak $4 \mathrm{~mm}, 10$ $\mathrm{mm}, 30 \mathrm{~mm}$ dan $70 \mathrm{~mm}$ dari garis pusat las. Dari gambar tersebut dapat dilihat bahwa grafik puncak terjadi saat sumber panas las bergerak dan terdekat dengan titik termokopel terpasang. Tiap titik termokopel memperlihatkan pemanasan sangat cepat sampai mencapai puncak, kemudian mulai pendinginan dengan lebih lambat ketika sumber panas menjauhi titik termokopel, sehingga sesuai dengan perumusan model double elipsoidal [14].

Temperatur maksimal pada heat input $936 \mathrm{~J} / \mathrm{mm}$ cenderung lebih tinggi dari heat input $846 \mathrm{~J} / \mathrm{mm}$ seperti diperlihatkan Gambar 5. Hal ini berbanding lurus dengan hasil pengukuran distorsi yang menyatakan bahwa kenaikan heat input memperbesar terjadinya distorsi. Dengan demikian, semakin tinggi temperatur maksimal saat pengelasan akan berakibat pada peningkatan distorsi khususnya distorsi lengkung.

Distorsi lengkung di sebabkan oleh tegangan thermal $\left(\sigma_{\mathrm{s}}\right)$ yang lebih besar dari tegangan buckling kritis $\left(\sigma_{c r}\right)$ dari bahan yang bekerja pada arah longitudinal di daerah logam las. Tegangan thermal $\left(\sigma_{s}\right)$ dipengaruhi salah satunya oleh heat input seperti ditunjukkan pada persamaan 2 [15].

$$
\sigma_{s}=\mu \frac{\alpha_{T}(q / v)}{c \rho h} . E
$$

Dengan $\mu=$ faktor kekakuan longitudinal, $\alpha_{T}=$ difusivitas panas, $q=$ heat input, $v=$ kecepatan las, $c \rho$ = panas spesifik per volume, $h=$ tebal bahan, dan $E=$ modulus elastisitas bahan. Sedangkan tegangan buckling kritis $\left(\sigma_{c r}\right)$ banyak dipengaruhi oleh parameter bahan dan dimensi benda las seperti ditunjukkan pada persamaan 3 [15].

$$
\sigma_{c r}=k \frac{\pi^{2} E h^{2}}{12\left(1-v^{2}\right) w^{2}}
$$

Dengan $k=$ konduktivitas panas, $h=$ ketebalan plat, $v$ = kecepatan las, $w=$ lebar strip las, $E=$ modulus elastisitas bahan.
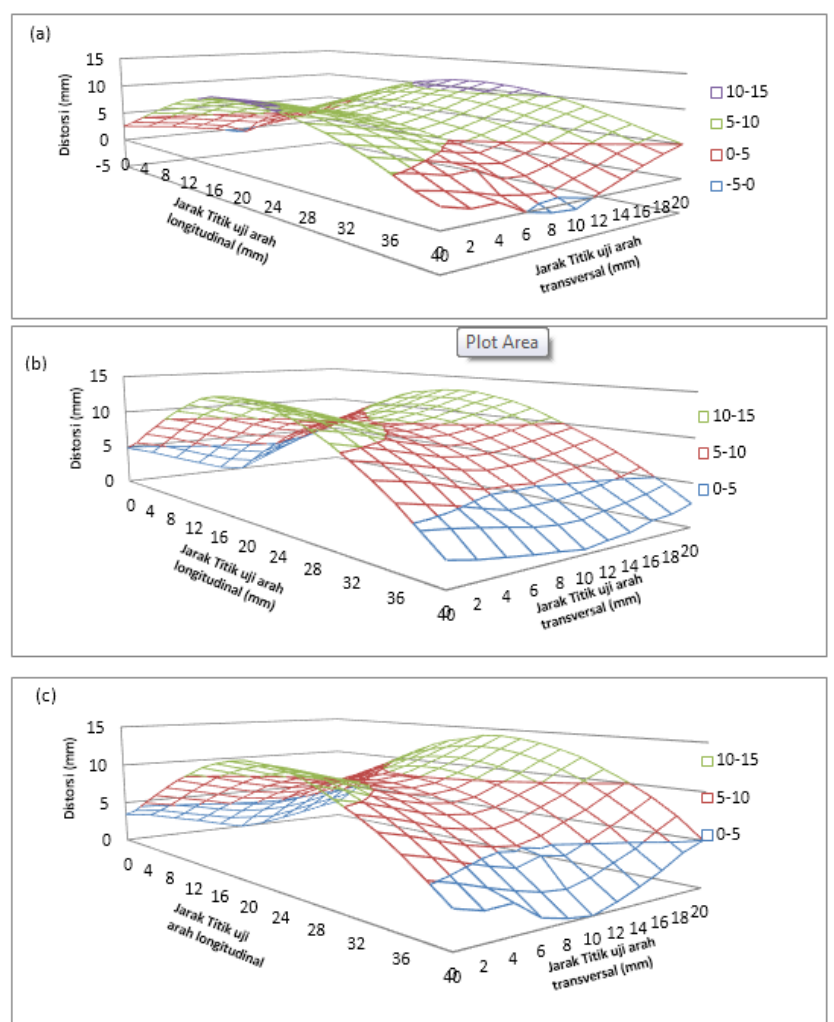

Gambar 4. Hasil pengukuran distorsi dengan variasi heat input: (a) $756 \mathrm{~J} / \mathrm{mm}$, (b) $846 \mathrm{~J} / \mathrm{mm}$, (c) $936 \mathrm{~J} / \mathrm{mm}$

Berdasarkan persamaan 2 didapatkan bahwa semakin besar heat input maka tegangan thermal semakin besar. Namun demikian tegangan yang melawan yaitu tegangan buckling kritis (persamaan 3) cenderung sama untuk parameter bahan dan dimensi 
yang sama. Dengan demikian kenaikan heat input akan diikuti oleh kenaikan tegangan thermal dan menyebabkan distorsi lengkung yang lebih besar.
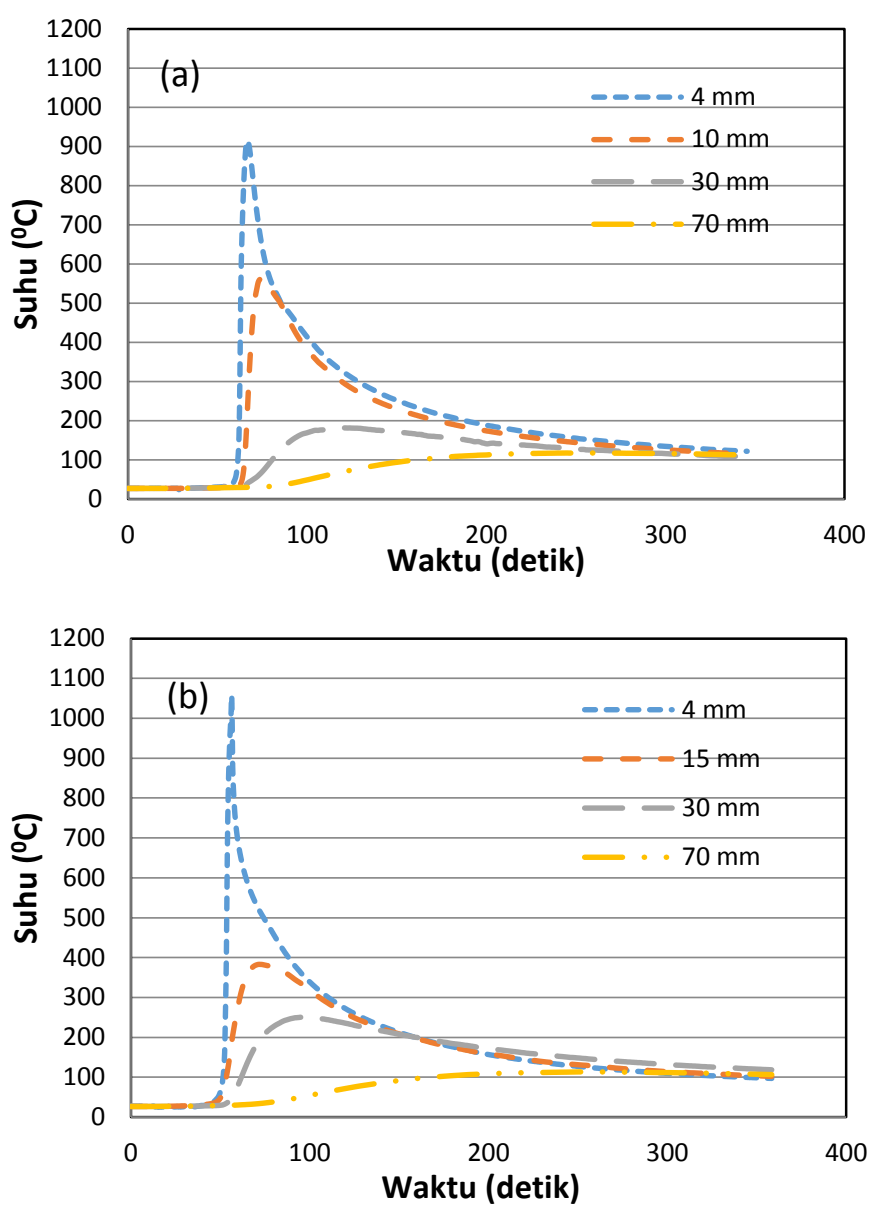

Gambar 5. Distribusi temperatur saat pengelasan pada berbagai jarak arah transversal pada heat input : (a) $846 \mathrm{~J} / \mathrm{mm}$, (b) $936 \mathrm{~J} / \mathrm{mm}$

\section{Analisa Mikrostruktur}

Struktur mikro hasil pengelasan baja karbon A36 dapat diklasifikasikan dalam 4 zona yaitu : welding zone (WZ), coarse grain heat affected zone (CG$\mathrm{HAZ}$ ), fine grain heat affected zone (FG-HAZ) and unaffected base metal (BM). Berdasarkan gambar 6 , 7 dan 8, batas WZ dengan CG-HAZ dapat dinampakkan pada struktur makro, dan diperjelas dengan tampilan struktur mikro pada keempat zona tersebut.

Berdasarkan Gambar 6 (a), 7 (a) dan 8 (a) dapat dilihat bahwa mikrostruktur logam induk (BM) memiliki struktur butiran oval memanjang yang sesuai dengan arah pengerolan. Selanjutnya pada daerah FG-HAZ terlihat butiran yang lebih halus dari BM yang ditunjukkan Gambar 6 (b), 7 (b) dan 8 (b). Hal ini terjadi akibat rekristalisasi butir setelah proses pengelasan. Daerah FG-HAZ ini diperkirakan berjarak 6 - 10 mm dari garis pusat las. Bila dihubungkan dengan grafik temperatur pada jarak tersebut (Gambar 5 a), pembentukan butiran halus pada FG-HAZ ini diperkirakan dibawah suhu $900{ }^{\circ} \mathrm{C}$. Mengacu pada Gambar 6 (c), 7 (c) dan 8 (c) ditampilkan butiran struktur mikro dengan diameter yang besar atau disebut daerah CG-HAZ. Demikian juga Gambar 6 (d), 7 (d) dan 8 (d) yang memperlihatkan batas yang sangat jelas antara CG-HAZ dengan WZ. Butiran kasar pada daerah CG-HAZ ini disebabkan pertumbuhan butir pada suhu tertentu dan cenderung memperlihatkan struktur Bainite.

Gambar 6 (e), 7 (e) dan 8 (e) memperlihatkan struktur mikro daerah WZ, menampilkan adanya struktur Acicular ferrite (AF), grain boundary ferrite (GF) dan Bainite yang cenderung memiliki kekuatan lebih tinggi dari Ferrite pada logam induk. Pengaruh heat input pada struktur mikro memperlihatkan pada heat input $936 \mathrm{~J} / \mathrm{mm}$ cenderung meningkatkan struktur Bainite namun mengurangi struktur AF dibanding heat input lainnya. Hal senada disampaikan Lee, dkk [16] bahwa semakin besar heat input akan mengurangi fraksi volume AF. Dengan demikian heat input mempengaruhi fraksi volume Bainite dan AF yang terjadi pada daerah WZ.

Pada Gambar 6 (f), 7 (f) dan 8 (f) menampilkan struktur makro pada las, yang sangat jelas terlihat bahwa semakin besar heat input mempengaruhi penetrasi las dan volume deposit logam las. Hal ini berkaitan dengan distorsi bahwa semakin besar heat input semakin memperbesar distorsi.
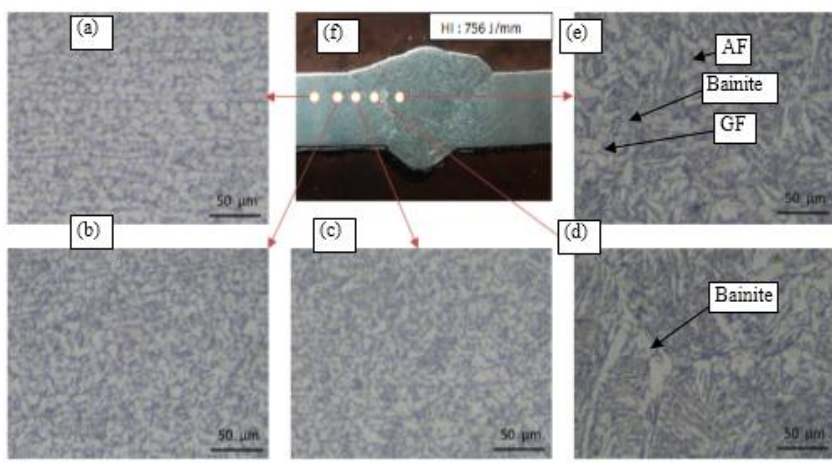

Gambar 8. Struktur mikro las : (a) BM, (b)batas BM dan FG-HAZ, (c) FG-HAZ, (d) batas CG-HAZ dan $W Z$, (e) WZ dan (f) penampang makro las pada heat input $756 \mathrm{~J} / \mathrm{mm}$.

\section{Distribusi kekerasan, kekuatan tarik dan ketangguhan}

Sifat mekanis sambungan las dilakukan dengan menganalisa kekerasan, kekuatan tarik dan ketangguhan sambungan las. Hasil pengukuran kekerasan ditampilkan dalam grafik distribusi kekerasan (Gambar 9), dengan membagi tingkat kekerasan dalam 4 zona las. Dalam grafik terlihat bahwa nilai kekerasan pada daerah BM adalah sekitar 140 - 150 HV. Sedangkan daerah FG-HAZ, CG-HAZ dan WZ berturut-turut adalah $150-180 \mathrm{HV}, 155-210$ HV dan 175 -220 HV.

Berdasarkan nilai kekerasan dari 4 zona diatas, terlihat bahwa kekerasan paling tinggi terletak di daerah CG-HAZ. Hal ini dikarenakan daerah HAZ kasar ini telah terbentuk struktur Bainite, yang memiliki kekuatan dan kekerasan tinggi. Sedangkan pada 
daerah butiran halus (FG-HAZ) secara degradasi menurun kekerasannya. Hal ini menunjukkan bahwa heat input las sangat mempengaruhi kekerasan terutama pada daerah CG-HAZ.

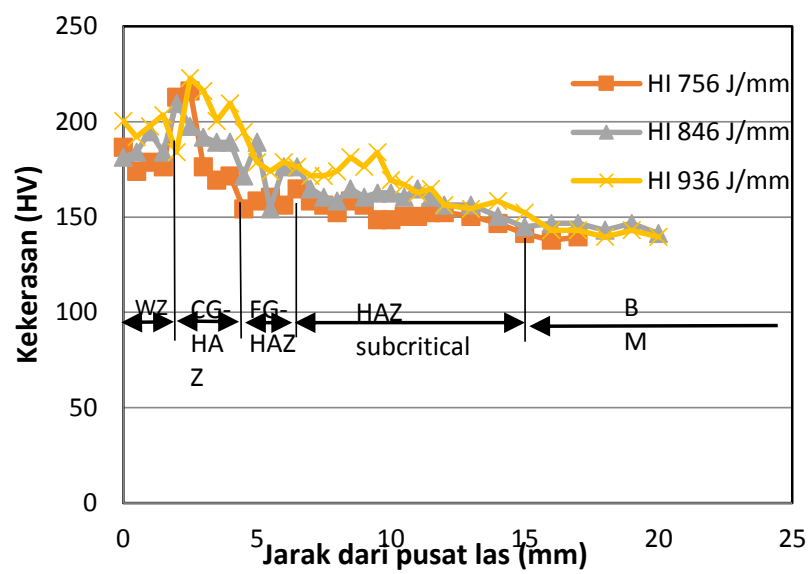

Gambar 9. Distribusi kekerasan pada heat input 756

$\mathrm{J} / \mathrm{mm}, 846 \mathrm{~J} / \mathrm{mm}$, dan $936 \mathrm{~J} / \mathrm{mm}$.

Perbandingan nilai kekerasan pada 3 variasi heat input menunjukkan kekerasan rata-rata daerah WZ, CG-HAZ dan FG-HAZ tertinggi pada heat input 936 $\mathrm{J} / \mathrm{mm}$, dan terendah pada heat input $756 \mathrm{~J} / \mathrm{mm}$ (Gambar 9). Dengan demikian kenaikan heat input akan cenderung menaikkan nilai kekerasan bahan. Kekuatan tarik sambungan las dilakukan dengan uji tarik arah transversal dan arah horisontal. Hasil pengujian tarik arah transversal (Gambar 10) menunjukkan kekuatan tarik sambungan las dengan variasi heat input cenderung memiliki nilai yang sama yaitu sekitar $480 \pm 7 \mathrm{MPa}$. Hal ini disebabkan patahan uji tarik terjadi pada daerah logam induk (BM), bukan di logam las atau HAZ. Gambar 12 menunjukkan patahan semua benda uji ada di daerah BM. Dengan demikian nilai kekuatan tarik arah transversal merupakan kekuatan tarik logam induk (BM).

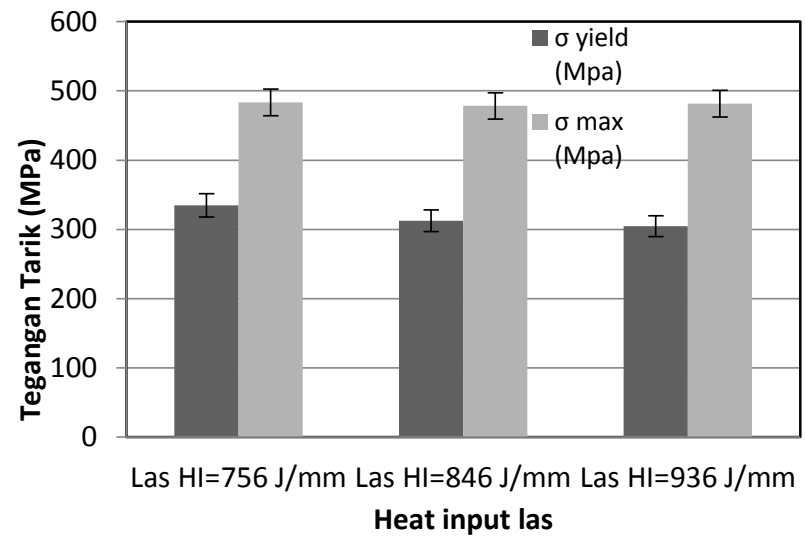

Gambar 10. Kekuatan tarik las arah transversal pada heat input $756 \mathrm{~J} / \mathrm{mm}, 846 \mathrm{~J} / \mathrm{mm}$, dan $936 \mathrm{~J} / \mathrm{mm}$.

Untuk mendapatkan nilai kekuatan tarik logam las, perlu dilakukan pengujian tarik longitudinal. Hasil pengujian tarik arah longitudinal ditampilkan pada Gambar 11. Hasil uji memperlihatkan kekuatan tarik las cenderung sama untuk HI $846 \mathrm{~J} / \mathrm{mm}$ dan 936
$\mathrm{J} / \mathrm{mm}$, yaitu sekitar $556 \pm 6 \mathrm{MPa}$ sampai $561 \pm 6 \mathrm{MPa}$. Namun untuk HI $756 \mathrm{~J} / \mathrm{mm}$ memiliki nilai kekuatan tarik agak rendah yaitu $539 \pm 7 \mathrm{MPa}$. Hal ini disebabkan ukuran logam las pada $\mathrm{HI} 756 \mathrm{~J} / \mathrm{mm}$ cenderung lebih kecil dibanding $\mathrm{HI} 846 \mathrm{~J} / \mathrm{mm}$ dan $936 \mathrm{~J} / \mathrm{mm}$. Hasil patahan memperlihatkan variasi heat input tidak mempengaruhi sifat patah ulet logam las yang dilihat dari nilai regangan setelah patah uji tarik transversal hampir sama dengan uji tarik longitudinal yaitu masing-masing 0,23\% dan 0,22\%. Dengan demikian bisa dinyatakan bahwa kekuatan tarik logam las (WZ) adalah sekitar $556 \pm 7 \mathrm{MPa}$ dan memiliki sifat patah ulet.

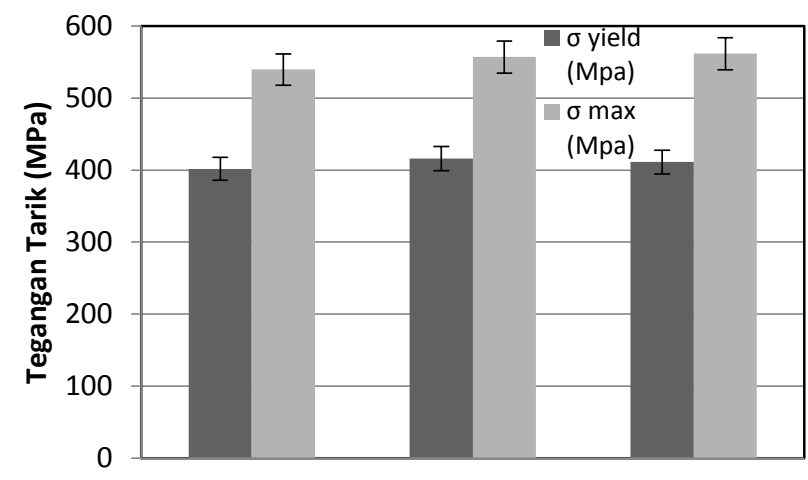

Las $\mathrm{HI}=756 \mathrm{~J} / \mathrm{mm}$ Las $\mathrm{HI}=846 \mathrm{~J} / \mathrm{mm}$ Las $\mathrm{HI}=936 \mathrm{~J} / \mathrm{mm}$ Heat input las

Gambar 11. Kekuatan tarik las arah longitudinal pada heat input $756 \mathrm{~J} / \mathrm{mm}, 846 \mathrm{~J} / \mathrm{mm}$, dan $936 \mathrm{~J} / \mathrm{mm}$.

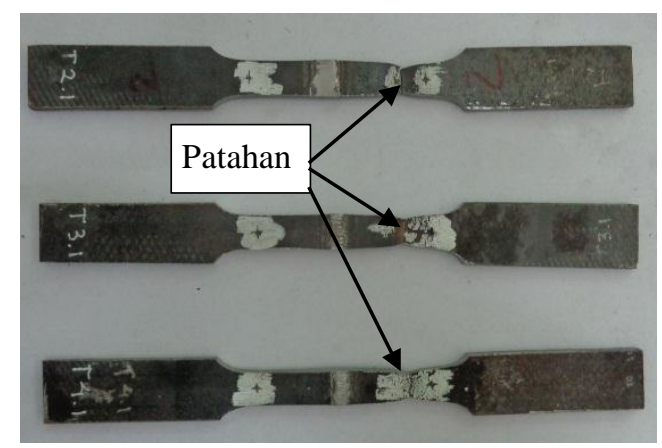

Gambar 12. Patahan uji tarik arah transversal.

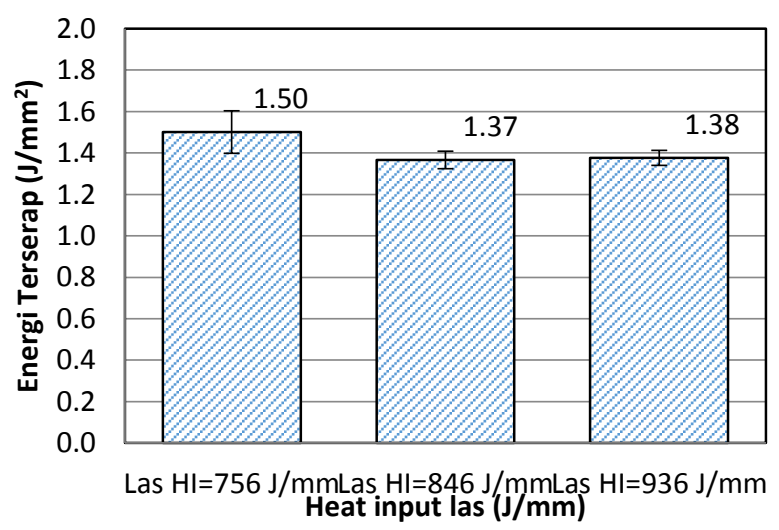

Gambar 13. Hasil uji impact las pada heat input 756 $\mathrm{J} / \mathrm{mm}, 846 \mathrm{~J} / \mathrm{mm}$, dan $936 \mathrm{~J} / \mathrm{mm}$. 
Ketangguhan sambungan las diselidiki dengan pengujian impact Charpy. Hasil pengujian impact diperlihatkan pada Gambar 13 menunjukkan bahwa heat input $756 \mathrm{~J} / \mathrm{mm}$ memiliki energi impact paling tinggi dibanding heat input lainnya yaitu sebesar $1,50 \mathrm{~J} / \mathrm{mm}^{2}$. Bila dihubungkan dengan nilai kekerasan, maka pada heat input $756 \mathrm{~J} / \mathrm{mm}$ cenderung memiliki tingkat kekerasan lebih rendah dibanding heat input lainnya. Lakshminarayanan, dkk [17] menyatakan bahwa peningkatan jumlah AF akan meningkatkan ketangguhan logam las. Hal ini sesuai dengan hasil struktur mikro dan hasil uji impact bahwa pada heat input $756 \mathrm{~J} / \mathrm{mm}$ fraksi volume AF paling banyak dibanding heat input lainnya sehingga menyebabkan ketangguhan bahan meningkat. Dengan demikian dapat dinyatakan bahwa heat input $756 \mathrm{~J} / \mathrm{mm}$ memiliki tingkat ketangguhan paling baik karena memiliki struktur AF paling banyak dibanding heat input lainnya.

\section{KESIMPULAN}

Berdasarkan pembahasan dapat diambil kesimpulan sebagai berikut:

1. Penurunan heat input akan memperkecil terjadinya distorsi arah longitudinal maupun distorsi arah transversal. Distorsi arah transversal maupun arah longitudinal minimal terjadi pada heat input $756 \mathrm{~J} / \mathrm{mm}$.

2. Pengaruh heat input pada struktur mikro memperlihatkan pada heat input $936 \mathrm{~J} / \mathrm{mm}$ cenderung meningkatkan struktur Bainite namun mengurangi struktur AF dibanding heat input lainnya.

3. Nilai kekerasan paling tinggi terletak di logam las (WZ) yang memiliki struktur Bainite terbanyak. Kenaikan heat input cenderung menaikkan nilai kekerasan di daerah WZ, CG-HAZ dan FG-HAZ.

4. Kekuatan tarik las arah transversal cenderung memiliki nilai yang sama yaitu $480 \pm 7 \mathrm{MPa}$ untuk semua heat input dan patah di daerah logam induk. Kekuatan tarik logam las (WZ) adalah sekitar 556 \pm MPa dan memiliki sifat patah ulet.

5. Heat input $756 \mathrm{~J} / \mathrm{mm}$ memiliki energi impact paling tinggi dibanding heat input lainnya yaitu sebesar $1,50 \mathrm{~J} / \mathrm{mm}^{2}$.

\section{DAFTAR PUSTAKA}

[1] Wiryosumarto, H., dan Okumura, T., (2000), Teknologi Pengelasan Logam, Pradnya Paramita, Jakarta.

[2] Michaleris, P., (2011), Minimization of welding distortion and buckling (Modelling and implementation), Woodhead Publishing, Cambridge CB22, UK.

[3] Wenkai, X., Li, Z., Fuju, Z., Kezun, D., Xian, Z., Xue, Y., Bingjun, C., (2015), Effect of heat input on cryogenic toughness of $316 \mathrm{LN}$ austenitic stainless steel NG-MAG welding joints with large thickness, Material and Design Journal 86 p.p 160-167.
[4] Popovic, O., Cvetkovic, R.P., Burzic, M., Milutinovic, Z., (2010), The effect of heat input on the weld metal toughness of surface welded joint, International Research/Expert Conference 14th, Mediterranean.

[5] Kianersi, D., Mostafaei, A., Amadeh, A., (2014), Resistance spot welding joints of AISI 316L austenitic stainless steel sheets: Phase transformations, mechanical properties and microstructure characterizations, Materials dan Design Journal 61 pp. 251 - 263.

[6] Waheed, R., Shakoor, A., Azam, K., Khan, A., Shah, F., (2015), Welding Distortion Control in Thin Metal Plates by Altering Heat Input through Weld Parameter, Technical Journal, UET Taxila, Pakistan Vol. 20(SI) No.II

[7] Andritsos, F., Prat, J. P., (2000), The otomation and integration of production processes in ship building, Joint Reserch Center, European Commission.

[8] American Society for Testing and Materials, 1999, ASTM A36 : Standard specification for Carbon Steel, Wahington D.C, USA.

[9] Cobe Steel (1991), Cobelco Welding Handbook, Cobelco welding of America Inc, USA.

[10]Miller Electric (2012), Guidelines For Gas Metal Arc Welding (GMAW), Tool Work Company, Appleton, USA

[11] Yoshiki, et al., (2006), Measurement and Numerical Simulation of Angular Distortion of Fillet Welded T-joint, Japan Welding Society vol.24, No. 4(20061105), pp.312-323.

[12] American Society for Testing and Materials, 2010, ASTM E-8: Standard Test Methods for Tension Testing of Metallic Materials, Pennsylvania, USA.

[13] American Society for Testing and Materials, 1997, ASTM A 370: Standard Test Methods and Definitions for Mechanical Testing of Steel Products, West Conshohocken, PA 19428-2959, United States.

[14] Goldak, J., Chakravanti, A., and Bibby, M., (1982), A new Finite Element Model for Welding Heat Sources, Metalurgical Transaction B, vol. $15 \mathrm{~B}$.

[15] Radaj, D., (1992), Heat Effects of Welding, Springer-Verlag, Berlin, Heidelberg.

[16] Lee, J.S., Jeong, S.H., Lim, D.Y., Yun, J.O., and Kim, M.H., (2010), Effects of Welding Heat and Travel Speed on the Impact Property and Microstructure of FC Welds, Met. Mater. Int., Vol. 16, No. 5 (2010), pp. 827 832.

[17] Lakshminarayanan, A.K. and Balasubramanian, V., (2011), Tensile and Impact Toughness Properties of Gas Tungsten Arc Welded and Friction Stir Welded Interstitial Free Steel Joints, Journal of Materials Engineering and Performance Volume 20(1) February 2011, p.p 82- 89. 